\title{
Wing Sails for Hybrid Propulsion of a Ship
}

\author{
Dalija Milić Kralj', Branko Klarin*2 \\ ${ }^{1}$ Faculty of Electrical and Mechanical Engineering and Naval Architecture, Ruđera Boškovića 32, 21000 \\ Split, Croatia \\ e-mail: dalia.milic-kralj@ skole.hr \\ ${ }^{2}$ Faculty of Electrical and Mechanical Engineering and Naval Architecture, Ruđera Boškovića 32, 21000 \\ Split, Croatia \\ e-mail: Branko.Klarin@fesb.hr
}

Cite as: Milić Kralj, D., Klarin, B., Wing Sails for Hybrid Propulsion of a Ship, J. sustain. dev. energy water environ. syst., 4(1), pp 1-13, 2016, DOI: http://dx.doi.org/10.13044/j.sdewes.2016.04.0001

\begin{abstract}
Various types of hybrid drives are increasingly being applied in transportation. Wing sails can provide additional propulsion to a motor-driven ship, thereby decreasing fossil fuel consumption. This article contributes to the selection and consideration of the influencing parameters for applying wing sails for ship propulsion. Basic developmental factors and application of wing sails are described. In addition, influential parameters and their relations are discussed. These parameters are connected to the physical and mechanical properties of wing sails and their impact on propulsion. It is important to recognize certain contributions of every influential parameter in relation to the final achievement. Parameters are ranked and described for several common types of sails, to find the best solution. Changing values of the influencing parameters on wing sails can significantly increase converted wind energy. The aim of this study was to note the parameters that influence the wing sail to drive ships more efficiently. Their importance is explained in an example based on the two most important sail types. This article evaluates the main parameters for a pointed semi-rigid wing with additional circulation for hybrid propulsion. All further research should be focused on this wing. Finally, guidelines for structural and operational changes in future wing sails are provided, which may assist developers in directing their efforts to discover a better solution for ship propulsion.
\end{abstract}

\section{KEYWORDS}

Wing sails, Wing sail parameters, Hybrid drive.

\section{INTRODUCTION}

According to [1], $90 \%$ of world trade is carried by sea, and this percentage continues to rise. Despite this fact, there is a need to reduce fuel consumption and emissions into the atmosphere. A computer program that takes into account wind speed and direction, as well as the direction of motion of a ship, optimizes the fuel economy of merchant ships, [1]. Rigid wing sails are an interesting and innovative way to utilize wind energy. Ships with rigid wing sails have certain advantageous features such as efficiency, security, ease of operation and computerized controls. A fuel as a source of propulsive energy causes pollution and is costly and hence not desirable. In comparison, a sail of any type releases no harmful emissions into the atmosphere. Therefore, ships with sails are economically and environmentally friendly. Therefore, they may be used for nautical and meteorological surveys, other research and even fishing in particularly environmentally

\footnotetext{
* Corresponding author
} 
sensitive areas. However, most are used for sports and leisure because this trend has been adopted from the conventional sail ships.

Wing sails are aerodynamically identical to the aircraft wing. The first recognizable application of the aerodynamic lift principle using semi-rigid sails can be found on Chinese junks and is several thousand years old. In other parts of the world, especially Europe, this principle began to be recognized after the Middle Ages. In [2], Marchay briefly describes various aspects of sailing.

\section{BASIC TYPES OF WING SAILS}

Wing sails, in concept, have a major drawback that is the result of their rigidity and hardness: their shape is unchanged. As an additional drawback, these sails exist in the current building technology had have a large mass and inertia. Thus, the main advantage of rigid sails in action becomes their main disadvantage when a ship is at rest or during strong winds.

Specifically, wing sails are not entirely reefable or stowable like traditional sails. Therefore, when a ship is at rest, or if a strong wind appears, the ship's safety and navigation may be endangered.

Today, there are different solutions for reefing or stowing these sails, such as the retractable-Magnus effect rotor [3], the deformable inflatable wing [4], the assemblage wing "Transitionrig" [5], a set of stowable rigid sails [6] and other technical solutions. However, these solutions have not yet been widely used.

Consequently, the main obstacle to the widespread use of wing sails is the impossibility of stowing or reefing. Moreover, in certain folding solutions, the complexity of mechanical structures, and hence their relatively high price, are the most common cause of low usage. There are three basic wing sail types with a high lift force: the Flettner rotor, the Turbosail and the multi-element wing sail.

The most commonly used type of rigid sail is the worst in respect of towing: a cylinder or Flettner rotor (Figure 1) and a Turbosail (Figure 2) showing the basic working principle.

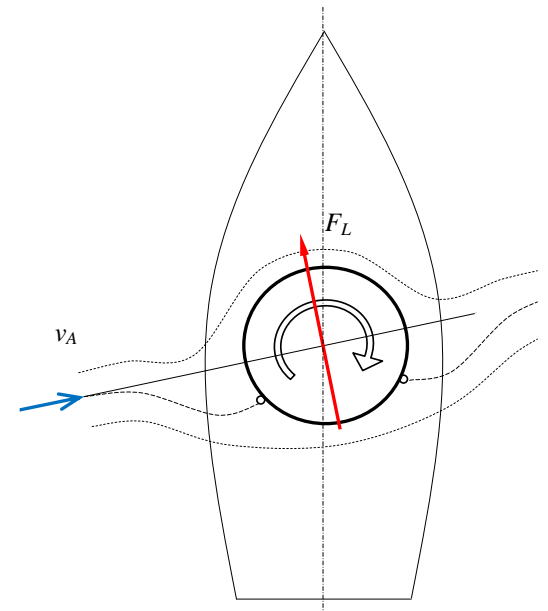

Figure 1. Basic principle of Flettner rotor usage (apparent wind speed $v_{A}$, lift force $F_{L}$ and rotation)

Both wing sail types use the attached flow effect. This effect retains the air particles along the airfoil skin and thus imposes more circulation $\Gamma$. The more attached the flow is, the greater the lift force. The ship of the famous explorer Jacques Cousteau, named 
Alycon, applies a Turbosail wing sail as the additional propulsion (Figure 2) [7]. The Turbosail, as a thick airfoil with flaps, applies under-pressure at the surface near the trailing edge. Thus, separation is avoided, and the lift force is up to four times better than that of the best modern wing sails. This solution is also not stowable.

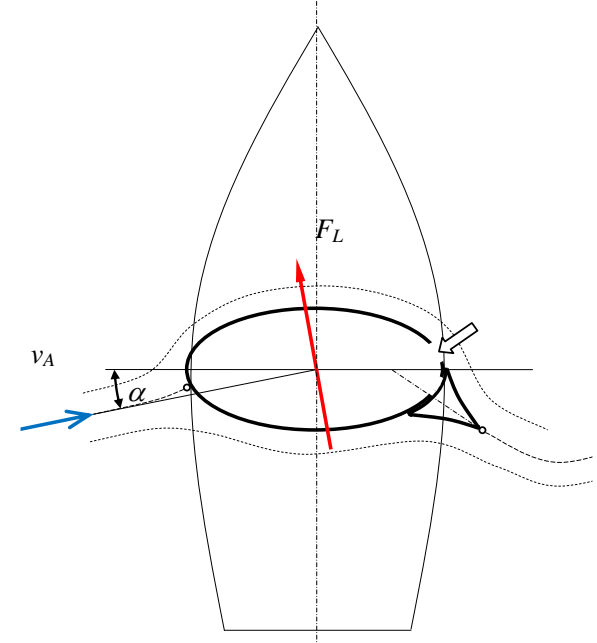

Figure 2. Basic principle of Turbosail usage (apparent wind speed $v_{A}$, lift force $F_{L}$ and circulation control)

Acceptable, interesting and usable solutions emerged as the result of research in toplevel sports developments: Formula 1, Rally, World Race and the America's Cup.

Evolutionary basis of modern sailing [8], for the America's Cup in the year 2014 was derived from the ship "Stars and Stripes" in the year 1988. Multi-element sail usage is shown in Figure 3.

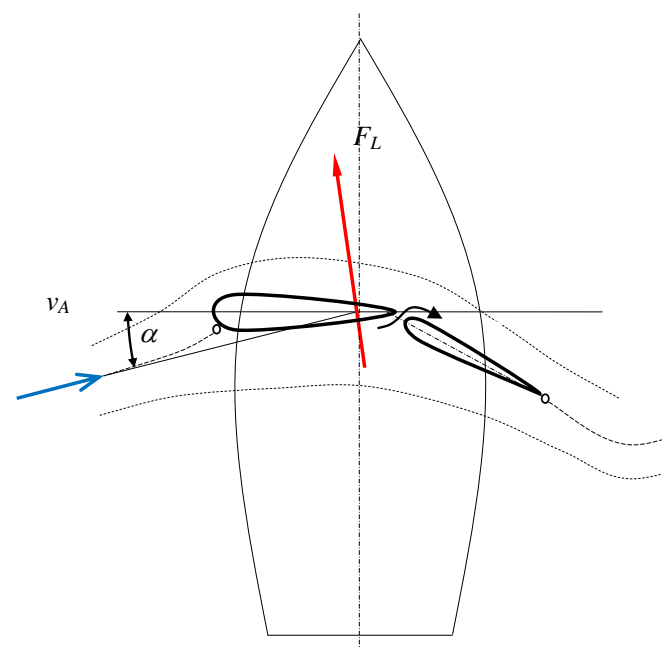

Figure 3. Basic principle of multi-element sail usage (apparent wind speed $v_{A}$, lift force $F_{L}$ and flap deflection with crossflow gap)

This type of wing sail, the multi-element wing sail, is the basic sail concept accepted by all teams in the competition. It consists of at least two airfoil-shaped parts, thus composing the high-lift device. The parts are symmetrical wing sails and auxiliary devices, if applied. Sailsare not a rigid structure but developed as old aircraft wings. Light 
and flexible aeronautical film material is used as a skin over the structure frame, according to [9].

Thus, the external geometry over airfoil ribs (carbon fiber, etc.), the supporting structure of the wing, makes the wing sail. Two or more airfoil-shaped parts of the wing cause increased lift force, which is further enhanced with gaps in between. These gaps engage the part of the air stream and turns over the tail section. The attached flow over the tail section further increases the lift force. At least one part of this wing sail can be stowable - the film material can be a reef with furling systems or similar components. Consequently, multi-element wing sails should be acceptable for future use on common ships.

Other types of wing sails provide a smaller lift force and will not be considered in this work.

The purpose of wing sails is additional propulsion for common ships because safety of navigation and a respectable timeline are expected. These systems will not replace the basic drive, mainly, internal combustion engines with fossil fuels [10-12].

\section{ANALYSIS OF INFLUENCING PARAMETERS}

From past knowledge and practice, based on observations and reasoning bionic principles, it may be concluded that the development of a sail is similar and that guided solutions are obtained through evolution and adopted from nature.

The wings are strong enough to allow flight and maneuvering during use and to stow or reef when not in use (birds). The development of sail forms that use the aerodynamic principle of operation follows the analogy and evolution in nature.

Based on this analogy and the sails' evolution, it can be hypothesized that an acceptable solution will be developed, either from the development of knowledge and construction, or from the technology of materials. The solution will enable a stiffened sail or wing sail to be reefed or stowed when not in use. It will be universally accepted and will yield wider use of wing sails. Based on observations, the next coefficients are obtained as in Table 1 [13-17].

Table 1. Drag and lift coefficients for different types of sails and their cross sections, axis of rotation, chord direction and auxiliary chord direction [13-17]

\begin{tabular}{|c|c|c|c|c|c|c|c|c|}
\hline & $\begin{array}{c}\text { Classic } \\
\text { sail }\end{array}$ & Indo-sail & $\begin{array}{l}\text { Rigid sail, i.e. } \\
\text { wingsail }\end{array}$ & $\begin{array}{c}\text { Rigid sail, i.e. } \\
\text { wing sail } \\
\text { with flap } \\
\end{array}$ & $\begin{array}{c}\text { Japanese } \\
\text { sail }\end{array}$ & $\begin{array}{c}\text { Two-component } \\
\text { semi-rigid wing } \\
\text { sail } \\
\end{array}$ & $\begin{array}{l}\text { Cousteau-Pechiney } \\
\text { turbo-sail }\end{array}$ & $\begin{array}{l}\text { Flettner } \\
\text { rotor }\end{array}$ \\
\hline Drag coefficient & 0.65 & 0.46 & $0.27-0.17$ & $0.65-0.45$ & 0.58 & $* * * 0.20-0.25$ & $* * 1.2-1.8$ & $* 0.5-4-5.6$ \\
\hline $\begin{array}{l}\text { Maximum lift } \\
\text { coefficient }\end{array}$ & $0.9-1$ & 1.5 & $1.1-2$ & $1.8-3.5$ & $1.5-2$ & $4-5$ & $5-6.5$ & $0-7-13$ \\
\hline $\begin{array}{c}\text { Sail or } \\
\text { wingappearance }\end{array}$ & & & & & & & & \\
\hline Typicalcross-section & - & & 0 & 17 & ४ & & & \\
\hline $\begin{array}{l}\text { Axisofrotation, } \\
\text { chord direction and } \\
\text { auxiliary chord } \\
\text { direction }\end{array}$ & & & 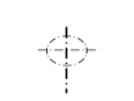 & & & & & \\
\hline
\end{tabular}

According to [18] an overview of the influential parameters on lift is presented in Table 2. 
Table 2. Influential parameters on wing behavior (lift) for different sail or wing types [18]

\begin{tabular}{|c|c|c|c|c|c|c|c|c|}
\hline & Classic sail & Indo-sail & $\begin{array}{l}\text { Rigid sail, } \\
\text { i.e. wing sail }\end{array}$ & $\begin{array}{l}\text { Rigid sail, } \\
\text { i.e. wing sail } \\
\text { with flap }\end{array}$ & Japanese sail & $\begin{array}{c}\text { Two- } \\
\text { component } \\
\text { semi-rigid } \\
\text { wing sail }\end{array}$ & $\begin{array}{l}\text { Cousteau- } \\
\text { Pechinay } \\
\text { turbo-sail }\end{array}$ & Flettner rotor \\
\hline $\begin{array}{c}\text { A brief } \\
\text { description of } \\
\text { the action }\end{array}$ & $\begin{array}{c}\text { Segmented } \\
\text { wing - wing } \\
\text { shape created } \\
\text { from several } \\
\text { independent } \\
\text { sail } \\
\text { segments, } \\
\text { placed } \\
\text { vertically in } \\
\text { height - } \\
\text { symmetry } \\
\text { around the } \\
\text { axis of } \\
\text { rotation }\end{array}$ & $\begin{array}{l}\text { Semi-rigid } \\
\text { sail - wing } \\
\text { shape created } \\
\text { from several } \\
\text { semi-rigid } \\
\text { sail segments } \\
\text { coupled } \\
\text { vertically in } \\
\text { height - } \\
\text { symmetry } \\
\text { around the } \\
\text { axis of } \\
\text { rotation }\end{array}$ & $\begin{array}{l}\text { Rigid sail - } \\
\text { single } \\
\text { component } \\
\text { profiled } \\
\text { segment - } \\
\text { symmetry } \\
\text { around the } \\
\text { plane of } \\
\text { rotation }\end{array}$ & $\begin{array}{l}\text { Rigid sail - } \\
\text { two } \\
\text { component } \\
\text { profiled } \\
\text { segment - } \\
\text { symmetry } \\
\text { around the } \\
\text { plane of } \\
\text { rotation }\end{array}$ & $\begin{array}{l}\text { Rigid wing - } \\
\text { wing shape } \\
\text { creates more } \\
\text { rigid } \\
\text { segments } \\
\text { profiled in } \\
\text { height - } \\
\text { symmetry } \\
\text { around the } \\
\text { axis of } \\
\text { rotation }\end{array}$ & $\begin{array}{l}\text { Semi-rigid } \\
\text { wing - two- } \\
\text { piece molded } \\
\text { segment - } \\
\text { symmetry in } \\
\text { the plane of } \\
\text { rotation }\end{array}$ & $\begin{array}{l}\text { Rigid wing - } \\
\text { two-piece } \\
\text { molded } \\
\text { segment with } \\
\text { forced } \\
\text { circulation - } \\
\text { symmetry in } \\
\text { the plane of } \\
\text { rotation }\end{array}$ & $\begin{array}{l}\text { Rigid } \\
\text { rotating } \\
\text { cylinder - } \\
\text { axis } \\
\text { symmetry }\end{array}$ \\
\hline $\begin{array}{l}\text { The most } \\
\text { influential } \\
\text { parameters }\end{array}$ & $v, \alpha$ & $v, \alpha$ & $v, \alpha$ & $v, \alpha$, geom. & $v, \alpha$, geom. & $v, \alpha$, geom. & $v, \alpha, \Gamma$, geom. & $v, \Gamma,(\omega)$ \\
\hline
\end{tabular}

These parameters have been chosen as the most important among many others and are used in a multicriteria analysis as most influenced in the subject evaluation. The most influential parameters to achieve lift are windspeed $v$ and angle of attack $\alpha$ for three basic types of wing. The wings also provide the worst lift results and are as follows:

- Classic sail or segmented wing;

- Indo-sail;

- Symmetrical rigid sail.

With the introduction of geometry as a variable parameter (geometry), in the two-part wing or wings that have the ability to change the geometry, i.e., airfoil (Junkers principle), the lift improves substantially.

Derived from $[2,13]$, relative or apparent wind speed $\vec{v}_{A}$, is emphasized as the first parameter, obtained as a vector sum of the true wind speed $\vec{v}_{T}$ and ship speed $\vec{v}_{S}$ (Figure 4).

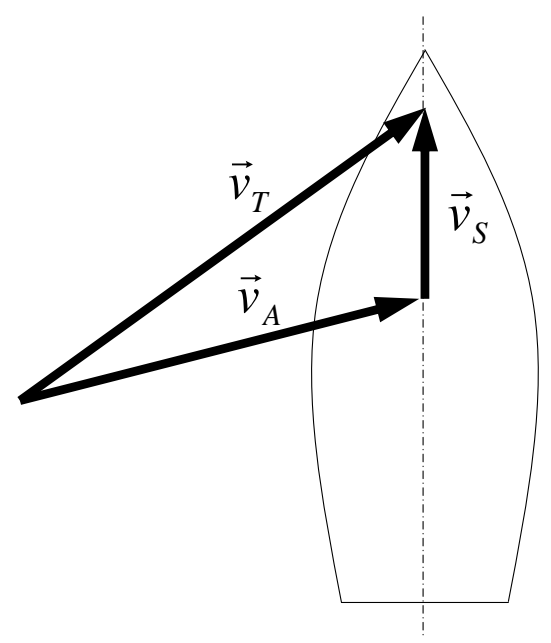

Figure 4. Relative or apparent wind speed $\vec{v}_{A}$, as a vector sum of the true wind speed $\vec{v}_{T}$ and ship speed $\vec{v}_{S}[14]$

Then, apparent wind speed $\vec{v}_{A}$, as a key parameter is used for calculating lift $F_{L}$ and $\operatorname{drag} F_{D}$ forces on the wing, according to eq. (1) and (2): 


$$
\begin{aligned}
& F_{L}=\frac{1}{2} C_{L} \rho v_{A}^{2} A \\
& F_{D}=\frac{1}{2} C_{D} \rho v_{A}^{2} A
\end{aligned}
$$

where:

- $C_{L}$ - lift coefficient;

- $C_{D}$ - drag coefficient;

- $A$ - reference surface of the wing $=$ airfoil chord $\times$ wing height.

When the transfer of wind energy is obtained through the pressure and velocity field on the wing geometry (Bernoulli principle), the wing structure accepts transformation into mechanical energy. The useful portion of the mechanical energy gives propulsion, and the other portion produces losses (elastic deformations, vibrations, heat dissipation, etc.). Angle of attack $\alpha$ is the next parameter to be considered when calculating lift and drag (wing behavior) $[19,20]$ (Figure 5).

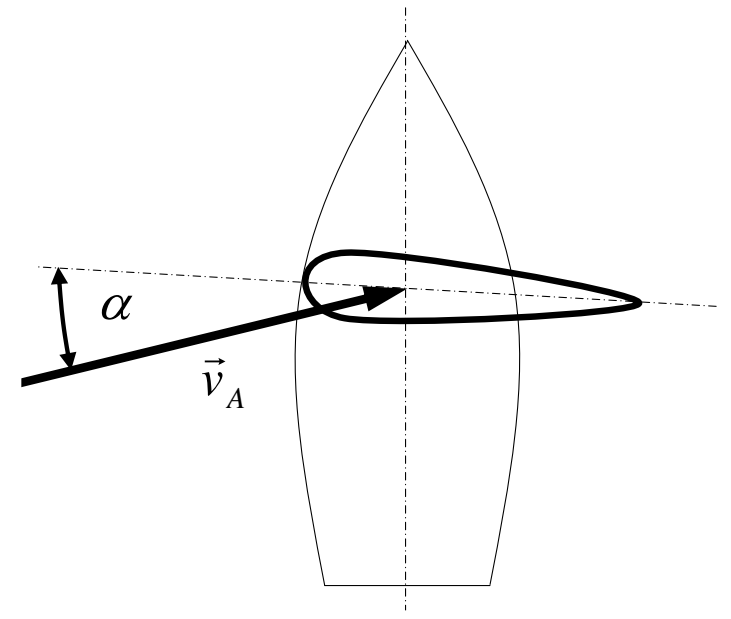

Figure 5. Relative wind speed $\vec{v}_{A}$ and angle of attack $\alpha$ on airfoil (wing) [14]

Lift and drag coefficients of the specified airfoil are dependent on the angle of attack. The first three types of sails (segmented, semi-rigid and rigid) are unchangeable or have a conditionally fixed geometry. The pressure and velocity fields around the airfoil, expressed through aerodynamic coefficients, change their values also in dependence of $\alpha$ [21]. The relative wind speed and angle are influential parameters on these sails.

Next, specified sails or wings have another more variable parameter: geometry. Thus, the pressure and velocity fields on the airfoil change because the airfoil shape changes. With geometry introduced as a variable parameter in two-piece wings or wings with a changeable geometry, i.e., airfoil, the lift is significantly improved (Junkers principle), as can be observed in contemporary two-component semi-rigid wings for America's Cup's racing sailboats, developed in the wake of the Stars and Stripes concept and applied on the boat that broke a speed record (Vestas Sailrocket 2, 2012.) [22]. Because of the possibility of the geometry change, the airflow over the sail (i.e., the wing) becomes more efficient. Consequently, because of the changing angle of attack $\alpha$ and sail area (surface), the influences of the above mentioned parameters are changed. This means also changing the drag and lift coefficients on various airfoil devices [23, 24]. Some solutions can be easily adapted to wing ship applications, [23-25]. 
The last and most influential parameter, namely, the flow around the airfoil, changes due to the attached flow effect, [26, 27].

Because of the relatively low power density of the wind, this parameter affects the increase in overall power density. Conventional sails with the same parameters of speed, angle of attack $(v, \alpha)$ and the geometry with the impact of $\Gamma$ parameter significantly gain efficiency.

In the special case of flow around a cylinder, when the intensity of circulation $\Gamma$ achieved by another independent parameter - angular velocity of cylinder rotation $\omega$, i.e., $\Gamma=f(\omega)$ (Magnus effect), the highest lift value is obtained but is also a method of making a completely different wing (Flettner rotor).

\section{EFFICIENCY, USABILITY AND FUTURE DEVELOPMENT}

It is known that the effectiveness of a wing sail and its practical application are in contradiction. Usability of wing sails means managing the operation and removal when necessary. Each recognized factor is important and does not exclude others from the final image of the applicability of rigid wings. However, from the engineering point of view, priority is given to the usability and conversion efficiency of wind power in a ship's thrust force. If these two factors are not achieved, the wing sail will not be accepted. This is the reason wing sails have not been commonly used. The masts are impractical as a board supplement if converted into specific non-removable shapes (plates, wings, sails, cylinders, etc.). It is not surprising that they are relatively rare in the application, i.e., they are used only for special purposes, [28-32].

Therefore, the influencing factors of development and their parameters are as follows:

- Engineering aspects: combine usability (functionality, reefability) and efficiency (efficiency, utility);

- Economic: combine the efficiency and economy (savings, cost-effectiveness);

- Financial: combine economy and technology (materials, production);

- Project: combine design (aerodynamics, shape) and technology;

- Design: combine design and practicality.

All factors are dependent and make a closed circle (Figure 6), according to [18].

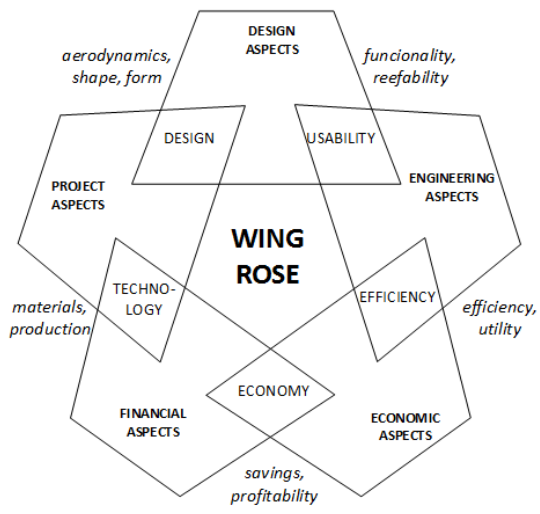

Figure 6. Basic developmental factors and a wing-sail application (Wing Rose), according to [18]

Functionality. The wing sail must be functional to obtain the target - additional drive of the ship, does not endanger the safety of navigation (additionally important), does not burden the construction of the ship in work as in rest (wind silence or mooring), does not interfere with the basic function of the ship (transport of people, transshipment cargo, 
etc.), turns on or off as needed, is easily handled (automation), has automatic and manual safety shutdown functions in the event of adverse weather conditions, is easy to maintain, etc.

Reefability. Wings are not reefable or stowable, and this is the main disadvantage of wing sails. The assumption is that the contemporary materials are very good and acceptable in consideration of their reefability from the main structure. For historic sport and leisure sails, this problem is solved. Solutions are sail canvasses or materials that allow bending, and thus the high surface area converts to a relatively small volume. Unfortunately, because of their flexibility and bending, these sails are far worse in terms of aerodynamic efficiency than wing sails are. Furthermore, after removing the sails, only the major carrier remains as the stationary fixed structure - the mast. This detail is unacceptable for wider use and substantially interferes with other functions of the ship, such as transshipment cargo. In addition, it is also complex for maintenance because the ties (cables) should be in perfect condition. On the one hand, reducing the mast and removing the ties will essentially increase the reefability of the sails. On the other hand, this also would reduce its aerodynamic thrust and construction hardness. The conclusion is that a solution satisfying the hardness and providing thrust should be found. This can only be achieved by increasing the power density and using wing sails.

Efficiency. It is necessary to applying the additional ship drive at minimum costs, investments and losses. The assumption is a generalized approach to this issue, which will result in a conceptual solution. This solution will allow adjustments to various situations, for example, on merchant ships, passenger boats, sports boats, etc. It is important to provide pre-conditions for minimizing future expenses, resources and losses.

Utility. The ratio of the resultant work, obtained from a wing sail with increased power density and work expended for increasing density is expected to be large; that is less invested work for the expected contribution. If this is not the case, this solution can satisfy neither economic nor financial aspects. If usability fails, the solution will be discarded.

Savings. This term is closely related to the previous terms, meaning that with the application of increased power-density wing sails, significant and visible savings are necessary to achieve. Savings plan refers to the (fossil) fuels and reducing harmful emissions into the atmosphere, especially $\mathrm{CO}_{2}$, which is, after all, declared through the $\mathrm{CO}_{2}$ tariffs as a market category.

Profitability. Investing in a wing sail with increased power density should define profitability, therefore evaluating the achieved utility. In addition to a cost savings, it is important to note that such a drive can also be traded with $\mathrm{CO}_{2}$ tariffs. These tariffs belong under the operation of the ship's use of fossil fuels. In other words, with applying the solution, a portion of the tariffs that would otherwise have to pay for use of the entire fossil fuel drive can be transferred to someone else. Because the $\mathrm{CO}_{2}$ emissions are a market category, the exchanges may qualify under various and more-or-less favorable conditions. Consequently, profitability can be further achieved as a direct saving of fossil fuels and profits from the sale of its $\mathrm{CO}_{2}$ tariffs.

Materials. Materials used for wings should enable the fulfillment of all aspects of their application and, in particular, the structural efficiency solutions. All suitable or 
contemporary materials specially developed for this purpose can be taken into consideration. Their basic characteristics are strength, flexibility, lightweight, usability, mass availability, etc. [33].

Production. The possibility of creating simple solutions is very important, i.e., without a large investment. Well-defined engineering, project and design aspects of the pre-decision makers ensure serial production of multifunctional wing sails, various types and sizes.

Aerodynamics. Aerodynamic efficiency is the basic starting point of a wing sail application and the most important parameter in the development and implementation of solutions. The ratio of lift and drag, that is, their projections on the sailing ship's direction, can affect the crucial choice between several solutions.

Form. Form solutions using rigid sails with increased power density should be on the trail of proven technical solutions. Their next purpose is to ensure the function and satisfaction of other aspects, contemporary or futuristic stylish and design features. Thus, the type of solution should be balanced design forms and engineering design.

If all aspects are not achieved as much as possible, the concept of wing sails will not be widely accepted, as is currently the case. The ideal solution, maximizing all parameters, does not exist.

It is possible to assign the certain contribution to every influential parameter in relation to the final achievement, and this is a wider application of the additional drive of the wing sail ships.

According to the previously mentioned factors, Table 3 is proposed. One column shows the weight fractions of the influential parameters, with the absolute amount of each factor from 0 to 1 ( 1 is the maximum value), and the other column lists the relative values of all together from 0 to 1 (percentage of the total value). Their order is from the most important at the top to the least significant at the bottom of Table 3 .

Table 3. Influential parameters and their values in the particular category

\begin{tabular}{cccl}
\hline Parametar & Aps. & Rel. & Category \\
\hline Aerodynamics & 1.0 & 0.164 & Technical \\
Profitability & 1.0 & 0.164 & Economy \\
Efficiency & 0.9 & 0.148 & Economy \\
Savings & 0.8 & 0.131 & Economy \\
Utility & 0.7 & 0.115 & Technical \\
Reefability & 0.7 & 0.115 & Technical \\
Functionality & 0.4 & 0.066 & Technical \\
Production & 0.3 & 0.049 & Technical \\
Materials & 0.2 & 0.033 & Technical \\
Form, shape & 0.1 & 0.016 & Technical \\
\hline
\end{tabular}

If the parameters are categorized and separated based on economics and technology, it should be noted that, although the technical parameters are numerically dominant, the economic parameters have priority and generally are placed at the top of the list. They contain a $44 \%$ share versus $56 \%$ technical. Hence, the importance of the division is half - half. This was expected and approximately reflects the actual division in all human spheres. 
In Table 4, the existing solutions to the previous parameterization are elaborated. An estimate of the degree is provided, and each of these previous solutions corresponds to one parameter, from 0 to 1 , for the several types of sails.

Table 4. Evaluation degree of several sail types by parameter

\begin{tabular}{cccccc}
\hline Parametar & Rel. & Classic & Flettner & Turbosail & Multi-element \\
\hline Aerodynamics & 0.164 & 0.2 & 1 & 0.8 & 0.7 \\
Profitability & 0.164 & 1 & 0.9 & 0.8 & 1 \\
Efficiency & 0.148 & 0.4 & 0.2 & 0.3 & 0.4 \\
Savings & 0.131 & 1 & 0.8 & 0.7 & 0.9 \\
Utility & 0.115 & 0.8 & 0.7 & 0.6 & 0.7 \\
Reefability & 0.115 & 0.9 & 0 & 0 & 0 \\
Functionality & 0.066 & 0.6 & 0.1 & 0.2 & 0.2 \\
Production & 0.049 & 0.7 & 0.3 & 0.2 & 0.1 \\
Materials & 0.033 & 0.7 & 0.1 & 0.1 & 0.4 \\
Form, shape & 0.016 & 0.2 & 0 & 0 & 0.1 \\
\hline
\end{tabular}

The evaluation results are shown in Table 5.

Table 5. The evaluation results of several sail types

\begin{tabular}{cccccc}
\hline Parametar & Rel. & $\begin{array}{c}\text { Classic } \\
\text { sail }\end{array}$ & $\begin{array}{c}\text { Flettner } \\
\text { rotor }\end{array}$ & Turbosail & $\begin{array}{c}\text { Multi-element } \\
\text { sail }\end{array}$ \\
\hline Aerodynamics & 0.164 & 0.033 & 0.164 & 0.131 & 0.115 \\
Profitability & 0.164 & 0.164 & 0.148 & 0.131 & 0.164 \\
Efficiency & 0.148 & 0.059 & 0.03 & 0.044 & 0.059 \\
Savings & 0.131 & 0.131 & 0.105 & 0.092 & 0.118 \\
Utility & 0.115 & 0.092 & 0.081 & 0.069 & 0.081 \\
Reefability & 0.115 & 0.104 & 0 & 0 & 0 \\
Functionality & 0.066 & 0.04 & 0.007 & 0.013 & 0.013 \\
Production & 0.049 & 0.034 & 0.015 & 0.01 & 0.005 \\
Materials & 0.033 & 0.023 & 0.003 & 0.003 & 0.013 \\
Form, shape & 0.016 & 0.003 & 0 & 0 & 0.002 \\
& $\Sigma$ & 0.683 & 0.551 & 0.494 & 0.569 \\
\hline
\end{tabular}

According to the summary results at the bottom of the Table 5, classic sails applied on boats for sport purposes and leisure are best rated. It is obviously that their usage and applicability yield corresponding grades. Turbosail has the lowest score and only a few examples can be found in practice. Then Flettner's rotors follow with a very rare application, mainly experimental and semi-rigid and multi-element wing sail from America's Cup. This type of sail has been extended and accepted in this ship class. The masts are a necessary but impractical addition on board. If turned in certain reefable shapes (plates, wings, sails, cylinders, etc.) they are relatively rare in the applications and are used only for special purposes. Note that the achievement of reefability on multielement wing sails can yield a better evaluation and even a different result. Reefability is strongly correlated with improved functionality. For example, here is an excerpt from Table 5. If we apply an imaginary reefablemulti-element wing sail with a mark of reefability of 0.9 and functionality of 0.6 in Table 4 , the same as for a classic sail, then 
we obtain following results in Table 6. Differences from Table 5 are bolded and underlined.

Table 6. The evaluation results of several sail types

\begin{tabular}{cccccc}
\hline Parametar & Rel. & $\begin{array}{c}\text { Classic } \\
\text { sail }\end{array}$ & $\begin{array}{c}\text { Flettner } \\
\text { rotor }\end{array}$ & Turbosail & $\begin{array}{c}\text { Multi-element } \\
\text { sail }\end{array}$ \\
\hline Aerodynamics & 0.164 & 0.033 & 0.164 & 0.131 & 0.115 \\
Profitability & 0.164 & 0.164 & 0.148 & 0.131 & 0.164 \\
Efficiency & 0.148 & 0.059 & 0.03 & 0.044 & 0.059 \\
Savings & 0.131 & 0.131 & 0.105 & 0.092 & 0.118 \\
Utility & 0.115 & 0.092 & 0.081 & 0.069 & 0.081 \\
Reefability & 0.115 & 0.104 & 0 & 0 & $0 \rightarrow \underline{0.104}$ \\
Functionality & 0.066 & 0.04 & 0.007 & 0.013 & $0.013 \rightarrow \underline{0.055}$ \\
Production & 0.049 & 0.034 & 0.015 & 0.01 & 0.005 \\
Materials & 0.033 & 0.023 & 0.003 & 0.003 & 0.013 \\
Form, shape & 0.016 & 0.003 & 0 & 0 & 0.002 \\
& $\Sigma$ & 0.683 & 0.551 & 0.494 & $0.569 \rightarrow \underline{0.728}$ \\
\hline
\end{tabular}

From the final result, it can be concluded that reefable wing sails (imaginary solution) are better rated than the usually applied conventional sails $(0.728$ vs. 0.683$)$.

On the other hand, the energy density of the wind, which turns on the unit area using the wing, is relatively small and depends linearly on the surface. Consequently, the principle, "The higher sail area is, the higher the thrust force", is unfavorable. For large (commercial or passenger) vessels, the usable wing area should reach a very high value and therefore can be unacceptable. This fact emphasizes that solutions with forced circulation or rotation achieve significantly greater conversion of the energy density per unit area.

In other words, changing the parameters influencing the efficiency of wind energy conversion can significantly increase the density and efficiency of converted energy with a wing. Under the influence of various parameters affecting rotation, i.e., the cylinder, the efficiency increases but the usability decreases. It can be concluded that the optimum balance between the simultaneous increase in both efficiency and usability can be achieved by using imposed circulation to existing solutions of the wing or semi-rigid wing sails, as shown in [34]. Reefability of the wings is essential feature of usability, and semi-rigid wings may be a better solution than rigid wings.

\section{CONCLUSION}

Previously, the best performance of wing sails have been achieved with the Flettner rotor, Turbosail and multi-element semi-rigid wings. It is expected to exclude the nonstowable cylinder as an impractical solution. Sail-driven boats for sporting purposes and leisure are best rated, and their distribution and applicability yield corresponding grades. Future improvements will be particularly focused on the area of performance of semirigid and rigid wing sails.

Currently, the two-element semi-rigid sail has been extended and accepted. Achievements in reefability can provide a better evaluation because of the strong correlation with improved functionality. Thus, wing sails may be better rated than conventional sails.

Changing the influencing parameters on the efficiency of wind energy conversion can significantly increase the density of converted energy using a wing. The optimum balance 
between the simultaneous increase of efficiency and usability can be achieved by applying imposed circulation to existing solutions of the wing or semi-rigid wing sails.

At the conclusion of this phase of wing sail research, the desirable characteristics are as follows:

- Wing sails should be as small as possible and therefore should apply high-lift devices;

- Sails or their skins should be reefable from the wing structure, in total or for the most part;

- High-lift force should be achieved with the imposed circulation so that the utilized energy is less than the obtained propulsion effect.

\section{REFERENCES}

1. Shukla, P. C., Ghosh, K., Revival of the Modern Wing Sails for the Propulsion of Commercial Ships, International Journal of Civil and Environmental Engineering, 2009.

2. Marchaj, C. A., Aero-Hydrodynamics of sailing, Adlard Coles, London, 1988.

3. http://google.com/patents/US4401284, [Accessed: 10-May-2015]

4. http://google.com/patents/US4895091, [Accessed: 10-May-2015]

5. Patent GB2225790.

6. google.com/patents/EP2409912A1?cl=en, [Accessed: 10-May-2015]

7. http://www.cousteau.org/about-us/alcyone, [Accessed: 10-May-2015]

8. http://33rd.americascup.com/en/contexte/que-sont-ilsdevenus/index.php?idIndex $=25$ \&idContent=665, [Accessed: 10-May-2015]

9. www.janicki.com, [Accessed: 10-May-2015]

10. Vukman, A., Analysis of Additional Ship Propulsion with Rigid Sail (in Croatian), B.Sc. work, FESB, Split, 2008.

11. Barišić, I., Analysis of Wind Potentials on Croatian Shore (in Croatian), B.Sc. work, FESB, Split, 2008.

12. Tatara, A., Analysis of Additional Ship Propulsion with Profiled Sail (Wing), Diploma work, FESB, Split, 2008.

13. Wilson, R. M., The Physics of Sailing, Dept. of Physics, Uni. of Colorado, 2010.

14. Klarin, B. and Milić Kralj, D., Rigid Wing Sails for Hybrid Propulsion of the Ship, Proc. 8th Conference on Sustainable Development of Energy, Water and Environment System SDEWES, Dubrovnik, FP423, 2013.

15. http://ntrs.nasa.gov/archive/nasa/casi.ntrs.nasa.gov/19930080992_1993080992.pdf -NACA-TN-228, [Accessed: 02-March-2013]

16. http://staff.civil.uq.edu.au/h.chanson/civ4160/alcyone.pdf, [Accessed: 10-May2015]

17. http://www.wired.com/magazine/2011/08/ff_americascup/all/?pid=6440, [Accessed: 10-May-2015]

18. Milić Kralj, D., PhD qualification work (in Croatian), FESB, Split, 2013.

19. Spera, D. A., Models of Lift and Drag Coefficients of Stalled and Unstalled Airfoils in Wind Turbines and Wind Tunnels, Jacobs Technology, Inc., Cleveland, Ohio, issued July 2012 for NASA/CR-2008-215434, 2008.

20. Patrick, F., Rynne, P. R. and von Ellenrieder, K. D., Development and Preliminary Experimental Validation of a Wind- and Solar-Powered Autonomous Surface Vehicle, IEEE Journal of Oceanic Engineering, Vol. 35., No. 4, 2010.

21. Gentry, A., The Aerodynamics of Sail Interaction, Proceedings of the third AIAA Symposium on the Aero/Hydronautics of Sailing, 1971.

22. www.vestas.com, [Accessed: 10-May-2015] 
23. Srinath, D. N. and Mittal, S., Optimal Aerodynamic Design of Airfoils in Unsteady Viscous Flows, Department of Aerospace Engineering, Indian Institute of Technology Kanpur, Elsevier, 2010.

24. Blakeley, A. W., Flay, R. G. J. and Richards, P. J., Design and Optimisation of MultiElement Wing Sails for Multihull Yachts, $18^{\text {th }}$ Australasian Fluid Mechanics Conference, Launceston, 2012.

25. Abbas, A., de Vicente, J. and Valero, E., Aerodynamic Technologies to improve Aircraft Performance, Aerospace Science and Technology, Vol. 28, 2013, http://dx.doi.org/10.1016/j.ast.2012.10.008

26. Dragan, V., Numerical Investigation of Coanda Lift on Double Curvature Super Circulated Ramp, Int. Journal of Civil and Structural Engineering, Vol. 2, No. 1, 2011.

27. Djokjodihardjo, H., et al, Numerical Simulation and Analysis of Coanda Effect Circulation Control for Wind Turbine Application Considerations, IIUM Engineering Journal, Spec. Issue, Mechanical Engineering, 2011.

28. Yoshimura, Y., A Prospect of Sail-Assisted Fishing Boats, Hokkaido University.

29. Klarin, B. and Biluš, K., Marine Transport with Common Sail Shipsand Perspectives (in Croatian), FESB, Split, 2007.

30. Kuethe, A. M. and Chow, C. Y., Foundations of Aerodynamics Bases of Aerodynamics Design, John Wiley\&Sons Inc., 1986.

31. Babinsky, H., How do Wings Work?, Dept. of Engineering, University of Cambridge, Cambridge, 2003.

32. Bogataj, P., How do Sails Work?

33. Clark, T., Preliminary Design of a Composite Wing-sail, 2010 SIMULIA Customer Conference.

34. Pfingsten, K. C. and Radespiel, R., Experimental and Numerical Investigation of a Circulation Control Airfoil, 47 ${ }^{\text {th }}$ AIAA Aerospace Meeting, Orlando, 2009. 